\title{
Application of Óbidos “Ginginha” by-products in topical formulations: A preliminary study
}

\section{Aplicação de sub-produtos da "ginginha" de Óbidos em formulações tópicas: Um estudo preliminar}

\author{
Elisabete Maurício ${ }^{1,2}$, Catarina Rosado ${ }^{1}$, Maria Paula Duarte ${ }^{3}$ \& Ana M. Díaz Lanza ${ }^{4}$ \\ ${ }^{1}$ Universidade Lusófona (CBIOS - Unidade de Dermatologia Experimental), Campo Grande, 376, \\ 1749-024, Lisboa, Portugal. \\ ${ }^{2}$ Elisa Câmara, Lda, dermocosmética, Talaide, 2785-601, S.Domingos de Rana \\ ${ }^{3}$ DCTB/UBiA, Universidade Nova de Lisboa/Faculdade de Ciências e Tecnologia, 2829-516 Caparica, Portugal. \\ ${ }^{4}$ Laboratorio de Farmacognosia, Área de Farmacología, Departamento de Ciencias Biomédicas , \\ Universidad de Alcalá (Madrid)(España). \\ Email: elisabetem@elisacamara.pt
}

\begin{abstract}
In recent years many studies on cherries have revealed that they are rich sources of bioactive compounds, mainly due to their polyphenolic phytochemicals. In this work, by-products of the sour cherry (Prunus cerasus L.) used in the Óbidos liquor from Portugal, were evaluated by determination of their total phenolic and anthocyanins contents. The mix samples (leaves and stems) and pomace (skins with and without kernels) were extracted by maceration using two different extraction methods with different solvents: ethanol and methanol. Overall, significant differences were observed between all the extracts in relation to the solvent used and anthocyanin and phenol contents. Stem and leaf extracts showed a polyphenol concentration higher than those from pomace. For all samples the total phenolic and anthocyanin contents were higher in methanol extracts than in ethanol extracts showing that methanol was the best solvent. For the pomace extracts the samples without kernels (skin samples) gave the highest values for both parameters. The tested cherry stems and pomace could be regarded as a promising agro-industrial by-product, being a low-cost polyphenols source, with potential to be added in functional cosmetics formulations. Further studies will be conducted to address their potential use as an antioxidant ingredient.
\end{abstract}

Keywords: Prunus cerasus; sour cherry; by-products; total phenolic content; anthocyanins; topical formulations.

\begin{abstract}
Resumo
Nos últimos anos estudos efectuados com frutos vermelhos têm revelado a sua riqueza em compostos bioactivos, sobretudo devido a presença de compostos polifenólicos. Neste trabalho foram avaliados os sub-produtos da ginja (Prunus cerasus L.) resultantes da indústria do licor de Óbidos, através da determinação do seu conteúdo em compostos fenólicos totais e, em particular, em antocianinas. As amostras de folhagens (pedúnculos e folhas) e de bagaço (película e película+caroço) foram extraídas por maceração através de 2 métodos de extracção diferentes, utilizando o etanol e o metanol como solventes. Na generalidade observaram-se diferenças significativas entre os teores em fenóis totais e antocianinas, quer dos extractos obtidos a partir de diferentes fracções (folhagem ou bagaço), quer dos extractos obtidos a partir da mesma fracção mas utilizando diferentes solventes. Os extractos das folhagens apresentaram valores de fenóis totais mais elevados que os extractos de bagaço. O metanol foi o solvente mais eficaz na extracção dos fenóis totais e das antocianinas para todas as amostras em estudo. Para as amostras de bagaço as amostras sem caroço (amostras de película) foram as que apresentaram valores mais elevados de fenóis totais e de antocianinas. Os resultados obtidos apontam no sentido dos sub-produtos agro-industriais analisados poderem constituir uma promissora fonte de compostos polifenólicos de custo reduzido, com potencial para aplicação em formulações dermocosméticas. Estudos futuros serão efectuados para avaliar o potencial destes resíduos como ingrediente antioxidante.
\end{abstract}

Palavras-chave: Prunus cerasus; ginja, sub-produtos; fenóis totais; antocianinas; formulações tópicas. 


\section{Introduction}

Plants, including fruits and vegetables, synthesize a wide range of secondary chemical compounds, that have protective functions important for plant survival ${ }^{[1,2]}$. Many of these are phenolic compounds and have been shown to have strong antioxidant, antiinflammatory, anti-viral, and anticarcinogenic activities $^{[3,4,5]}$.

Oxidative and inflammatory processes are related to aging, and to the onset of various disorders like cancer, diabetes, cardiovascular diseases, autoimmune diseases and neurodegenerative disorders. In this context antioxidant compounds may play an important role in preventing these diseases. In fact, in recent years, concern about the potential of polyphenolic antioxidants to combat the effects of oxidative stress and inflammation in aging processes and in neurodegenerative diseases has grown dramatically ${ }^{[6,7]}$. Free radicals play an important role in tissue aging, including that of the skin, and are also responsible for genotoxic effects on the cells. Thus, the use of antioxidants in skin cosmetics and topical products aims to combat these adverse effects, blocking the chemical reactivity of radicalar species in target tissues, thereby retarding its effects ${ }^{[8]}$.

Many red berries contain macro and micronutrients such as vitamins, minerals and fiber, being among the most significant food sources of phenolic compounds. Many of these berries proved to have antioxidant, antiinflammatory, anti-viral, and anticarcinogenic activities, which seems to be related to their phenolic content. There are several published studies concerning the use of extracts produced from food industry by-products as antioxidant ingredients in skin cosmetics. The case of sub-products of the wine industry is well known, with the concept of vinotherapy widely applied to cosmetic formulations ${ }^{[9}$, ${ }^{10,11]}$. Sour cherry (Prunus cerasus L., Rosaceae) has high phenolic content, especially a high anthocyanin content. Recent studies have shown that these compounds have strong antioxidant activity and therefore, the interest in these fruits has intensified because of their possible health benefits ${ }^{[12]}$.

The profile of bioactive compounds of Óbidos "Ginjinha" by-products is not described in the literature. However, the economic importance of this fruit in the region where it is produced justifies the increase in interest from the producers in exploring new applications of these by-products. A preliminary chemical characterization of Óbidos "Ginjinha" byproducts will allow for the evaluation of its potential for use as a bioactive ingredient in topical products and dermocosmetics.

\section{Introdução}

As plantas, incluindo frutos e vegetais, sintetizam uma vasta gama de compostos químicos secundários, que detêm funções de protecção importantes para a sua sobrevivência ${ }^{[1,2]}$. Muitos destes compostos são de natureza fenólica e têm demonstrado possuir elevada capacidade antioxidante, anti-inflamatória, antimutagénica, anticarcinogénica e antiviral ${ }^{[3,5,3]}$.

Os processos oxidativos e inflamatórios estão relacionados com o envelhecimento e com o surgimento de diversas patologias, como, por exemplo, cancro, diabetes, doenças cardiovasculares, doenças autoimunes ou doenças neurodegenerativas. Desta forma, os compostos antioxidantes podem desempenhar um papel importantíssimo na prevenção destas doenças. De facto, nos últimos anos, o interesse sobre os efeitos dos antioxidantes polifenólicos no combate ao efeito do stress oxidativo e inflamação nos processos de envelhecimento e em doenças neurodegenerativas tem vindo a crescer de forma notável ${ }^{[6,7]}$.

Por outro lado, uma boa parte dos efeitos de envelhecimento dos tecidos, nomeadamente da pele, é devida à formação de radicais livres, podendo estes ser igualmente responsáveis por efeitos de genotoxicidade observados nas células. Desta forma, o uso terapêutico de antioxidantes em produtos tópicos e dermocosméticos pode ajudar a combater este efeito nocivo, bloqueando a reactividade e retardando os efeitos das espécies radicalares nos tecidos alvos ${ }^{[8]}$.

Os frutos vermelhos contêm macro e micronutrientes, tais como vitaminas, minerais e fibra, estando entre as fontes alimentares mais ricas em compostos fenólicos. Muitos destes frutos têm vindo a demonstrar bioactividade, como, por exemplo, propriedades antioxidantes ou antiinflamatórias, que parecem estar relacionadas com o elevado nível e com a diversidade de compostos do tipo polifenólico que apresentam. Na literatura podem encontrarse alguns estudos sobre a utilização de extractos com origem em sub-produtos da indústria alimentar como ingredientes antioxidantes em produtos dermocosméticos. Destaca-se o caso dos sub-produtos da indústria vinícola, com o conceito $\mathrm{da}$ vinoterapia largamente aplicado às formulações cosméticas ${ }^{[9,10,11]}$.

A ginja (Prunus cerasus L., Rosaceae), possui um elevado teor em compostos fenólicos, especialmente antocianinas, que têm revelado em estudos recentes a sua actividade antioxidante, tendo, por isso, sido intensificado o interesse nestes frutos devido aos possíveis benefícios que podem ter para a saúde humana ${ }^{[12]}$.

O perfil de compostos bioactivos dos sub-produtos da "Ginjinha" de Óbidos não se encontra descrito na literatura. Contudo, a importância económica deste fruto na região da sua produção, vem justificando um interesse maior, por parte dos produtores em explorar novas aplicações destes sub-produtos. A caracterização química preliminar dos sub-produtos permitirá avaliar o seu potencial para utilização como ingrediente bioactivo em produtos tópicos e de dermocosmética. 


\section{Materials and Methods}

\section{Samples for analysis}

The "ginginha" liquor by-products were provided by Frutóbidos enterprise, from Óbidos in Portugal. The cherries used in the manufacture of liquor are an autochthonous culture from the region of Sobral in Óbidos. Samples for analysis are related to the crop of 2009 and are constituted by by-products: leaves and stems in mix form, and pomace with and without kernel. The last samples resulted from cherry industrial pressing. After collection, samples were transported in cold conditions to the Experimental Dermatology laboratory at the Lusófona University. Pomace samples were immediately stored at $-20^{\circ} \mathrm{C}$ and the stems and leaves were dried at $25^{\circ} \mathrm{C}$ for one month in a dark and cool room.

\section{Extraction}

Extractions were performed under reduced-light conditions. Samples were ground in a coffee mill for 3 minutes in order to reduce the particle size and increase the surface area. In this study three kinds of samples were used for extract preparation: Mix (leaves and stems), complete pomace (skin with kernel) and skins after manual removal of the kernels. The extracts were prepared with two solvents methanol and ethanol acidified with $0.1 \% \mathrm{HCl}$ following two different methodologies (adapted from 13):

Method $\mathrm{n}^{\circ} 1$ - By-products were macerated in acidified $(0.1 \% \mathrm{HCl})$ solvent (methanol or ethanol) in a $1: 10$ (w/v) plant/solvent proportion for 2 hours under constant agitation at $700 \mathrm{rpm}$ at low temperature and protected from light. Samples were filtered on filter paper (P5 quantitatve; Fisher Scientific, Pittsburgh,Pa.) and the first fraction of filtrate was collected. The residue obtained was mixed with a second identical volume of acidified solvent, stirred an additional 20 minutes, and filtered. Filtrates were combined and the solvent was evaporated in a rotary evaporator (Buchi RE11) at $40^{\circ} \mathrm{C}$ until complete evaporation. The extracts were then diluted in propylene glycol and water in the ratio of 1:1:4(w/v).

Method ${ }^{\circ} 2$ - By-products were macerated in acidified methanol $(0.1 \% \mathrm{HCl})$ in a $1: 10(\mathrm{w} / \mathrm{v})$ plant/solvent proportion for 2 hours under constant agitation at 700 rpm at low temperature and protected from light. Samples were filtered on filter paper (P5 quantitatve;Fisher Scientific, Pittsburgh,Pa.) and the first fraction of filtrate was collected. The residue obtained was mixed with a second identical volume of

\section{Material e Métodos}

\section{Recolha das amostras}

Os sub-produtos foram cedidos pela empresa Frutóbidos, cediada em Òbidos, Portugal. A ginja utilizada no fabrico do licor é proveniente das ginjeiras da região do Sobral em Óbidos. As amostras para análise são referentes à colheita de 2009 e são constituídas pelos sub-produtos: folhas e pedúnculos constituindo a amostra mista e pelo bagaço com e sem caroço. As últimas amostras são resultantes da operação de prensagem do fruto. Após recolha, as amostras foram transportadas em arca térmica até ao laboratório da Unidade de Dermatologia Experimental da Universidade Lusófona. As amostras foram armazenados e imediatamente congeladas a $-20^{\circ} \mathrm{C}$. As folhagens e pedúnculos foram secos a $25^{\circ} \mathrm{C}$ durante 1 mês em sala escura e fresca.

\section{Preparação dos extractos}

Os extractos foram preparados sob condições de luminosidade reduzida. As amostras foram trituradas em moinho de café durante 3 minutos de modo a reduzir o tamanho das partículas e incrementar a sua área superficial Neste estudo foram consideradas três extractos: Misto (folhas e pedúnculos), bagaço completo (películas e caroços) e películas após remoção manual do caroço do bagaço. A extracção (adaptado de 13) foi efectuada com metanol ou etanol acidificados com $0,1 \% \mathrm{HCl}$ seguindo duas metodologias diferentes:

Método $\mathrm{n}^{\mathrm{0}} 1$ - Maceraram-se as amostras no solvente acidificado (etanol ou metanol) com $0,1 \% \mathrm{HCl}$ numa razão de 1:10 durante duas horas sob agitação constante de $700 \mathrm{rpm}$ em temperatura baixa e protegidos da luz. Filtraram-se as amostras em papel de filtro (P5 quantitativo; Fisher Scientific, Pittsburgh, Pa.) e foi colhida a primeira fracção de filtrado. Ao resíduo obtido adicionou-se um volume igual de solvente acidificado, agitou-se mais 20 minutos, filtrou-se novamente e foi colhida a $2^{\mathrm{a}}$ fracção de filtrado. As duas fracções foram misturadas e o filtrado obtido foi a evaporar em evaporador rotativo (Buchi RE11) a $40^{\circ} \mathrm{C}$ até evaporação completa. $\mathrm{O}$ extractos obtidos foram diluídos em propilenoglicol e água na razão de $1: 1: 4(\mathrm{p} / \mathrm{v})$.

Método $\mathrm{n}^{\mathrm{0}} 2$ - Maceraram-se as amostras em metanol acidificado com $0,1 \% \mathrm{HCl}$ numa razão de $1: 10$ durante 20 minutos sob agitação constante de $700 \mathrm{rpm}$ a baixa temperatura e protegidos da luz. Filtraram-se as amostras em papel de filtro (P5 quantitativo; Fisher Scientific, Pittsburgh, Pa) e foi colhida a primeira fracção de filtrado. Ao resíduo obtido adicionou-se um volume igual de solvente acidificado, agitou-se mais 
acidified solvent, stirred an additional 20 minutes, and filtered. This procedure was repeated two more times. The four filtrate fractions were mixed and the solvent was evaporated in a rotary evaporator (Buchi RE11) at $40{ }^{\circ} \mathrm{C}$ until complete evaporation. The extracts were then diluted in propylene glycol and water in the ratio of $1: 1: 4(\mathrm{w} / \mathrm{v})$.

Extracts were stored at $-20^{\circ} \mathrm{C}$ for further analysis. All the analytical procedures were performed in triplicate.

\section{Total phenolic content}

Total phenolic content was determined with FolinCiocalteu reagent using gallic acid as a standard ${ }^{[1,15]}$. Briefly, $100 \mu \mathrm{L}$ of each extract (or its dilutions) were mixed with $500 \mu \mathrm{L}$ of Folin-Ciocalteu reagent (Sigma) and $1.5 \mathrm{~mL}$ of sodium carbonate $20 \%(\mathrm{w} / \mathrm{v})$. The absorbance at $765 \mathrm{~nm}$ was measured after two hours of incubation in the dark at $25^{\circ} \mathrm{C}$. Total phenolics were calculated with respect to gallic acid standard curve (concentration range: $50-500 \mathrm{mg} / \mathrm{L}$ ). Results were expressed in gallic acid equivalents (GAE) $\mathrm{mg} / 100 \mathrm{~g}$ of plant material.

\section{Total anthocyanin content}

Total anthocyanins content was estimated by the $\mathrm{pH}$ differential method ${ }^{[16]}$. Absorbance was measured at $510 \mathrm{~nm}$ and at $700 \mathrm{~nm}$ in buffers at $\mathrm{pH} 1.0$ (potassium chloride, $0.025 \mathrm{M}$ ) and $\mathrm{pH} 4.5$ (sodium acetate $0.4 \mathrm{M}$ ). Results were expressed in mg of cyanidin 3-glucoside equivalents (eq C-3-G)/100 g of fruit material, using a molar extinction coefficient of $29600 \mathrm{Lmol}^{-1} \mathrm{~cm}^{-1}{ }^{[16]}$.

\section{Statistical analysis}

The statistical analysis was performed using ANOVA and $\mathrm{t}$-Test, using a significance level of 0.05 (Excel 2010 Microsoft, Redmond EUA).

\section{Results and Discussion}

Total phenolic content for samples extracted with ethanol and methanol according to the method $\mathrm{n}^{\circ} 1$ varied from 15.26 to $1400.0 \mathrm{mg}$ GAE/100 $\mathrm{g}$ of plant (fig. 1). Significant differences $(p<0.05)$ were observed between the phenol content of the several samples in relation to its composition (skin, skin+kernel and mix), or in relation to the solvent used (methanol or ethanol). Mix extracts (stems and leaves) showed the highest polyphenol content, followed by the skin extracts and finally, the extracts obtained from skins with kernel, which showed the lowest values
20 minutos, filtrou-se novamente e foi colhida a segunda fracção de filtrado. Este procedimento foi repetido mais duas vezes cada uma durante 20 minutos. As quatro fracções de filtrado obtidas foram misturadas e evaporadas em evaporador rotativo (Buchi RE11) até evaporação completa. Os extractos obtidos foram diluídos em propilenoglicol e água na razão de 1:1:4(p/v).

Os extractos foram conservados a $-20^{\circ} \mathrm{C}$ para as determinações analíticas. Todas as determinações analíticas foram efectuadas em triplicado.

\section{.Quantificação dos fenóis totais}

O conteúdo em fenóis totais foi determinado pelo método de Folin-Ciocalteu ${ }^{[14,15]}$ misturando $100 \mu \mathrm{L}$ de cada um dos extractos (ou de suas diluições), com $500 \mu \mathrm{L}$ de reagente de Folin-Ciocalteu (Sigma), 1,5 mL de carbonato de sódio a $20 \%(\mathrm{p} / \mathrm{v})$ e água até $10 \mathrm{~mL}$. Após incubação de duas horas no escuro a $25^{\circ} \mathrm{C}$ para desenvolvimento de cor, foram efectuadas as leituras espectrofotométricas a 765 nm. O conteúdo em fenóis foi calculado através da construção de uma curva de calibração de ácido gálico (concentração entre: 0,5 e $5 \mathrm{mg} / \mathrm{L}$ ). Os resultados foram expressos em $\mathrm{mg}$ de equivalentes de ácido gálico (EAG) por $100 \mathrm{~g}$ de amostra fresca, para os extractos de bagaço completo e películas, e por $100 \mathrm{~g}$ de amostra seca, para os extractos mistos (folhas e pedúnculos).

\section{Quantificação das antocianinas totais}

$\mathrm{O}$ total de antocianinas foi determinado através do método do $\mathrm{pH}$ diferencial ${ }^{[16]}$. Assim, os extractos foram diluídos numa solução de cloreto de potássio $0,025 \mathrm{M}$, a pH 1,0 e em tampão de acetato de sódio $0,4 \mathrm{M}$ a pH 4,5, tendo a absorvância sido lida a $520 \mathrm{~nm}$ e a $700 \mathrm{~nm}$. Os resultados foram calculados usando o coeficiente de extinção molar de $29600 \mathrm{Lmol}^{-1} \mathrm{~cm}^{-1}$ e expressos em mg equivalentes de cianidina-3-glucósido (eq C-3-G) por $100 \mathrm{~g}$ de amostra fresca, para os extractos de bagaço completo e películas, e por $100 \mathrm{~g}$ de amostra seca, para os extractos mistos (folhas e pedúnculos).

\section{Análise Estatística}

A análise estatística foi efectuada através da análise de variância (ANOVA), e do teste t, adoptando-se um nível de significância de 0,05 (Excel 2010, Microsoft, RedmondEUA).

\section{Resultados e Discussão}

Os valores de fenóis totais das diferentes amostras extraídas com etanol e com metanol de acordo com o método $\mathrm{n}^{\circ} 1$ variaram entre e os 15,3 e os $1400,0 \mathrm{mg}$ GAE/100 g (fig.1). Através da análise estatística, foi possível verificar que existiram diferenças significativas $(p<0,05)$ entre o teor de fenóis das diversas amostras quer em relação a sua composição (película, película+caroço e mistos), quer em relação ao solvente. Para cada um dos solventes utilizados os extractos mistos foram os que mostraram os valores de 
(fig.1). For all samples analyzed, total phenols values were always higher when the extraction was performed with methanol than with ethanol. Thus it can be concluded that methanol was the most effective solvent. fenóis totais mais elevados, seguindo-se os extractos obtidos com as películas e, finalmente, os extractos obtidos com as películas com caroço, que registaram os valores mais baixos (fig.1). Para todas as amostras em estudo os valores de fenóis totais foram sempre mais elevados quando a extracção se processou com o metanol do que com o etanol. Desta forma é possível concluir que o metanol foi o solvente mais eficaz.

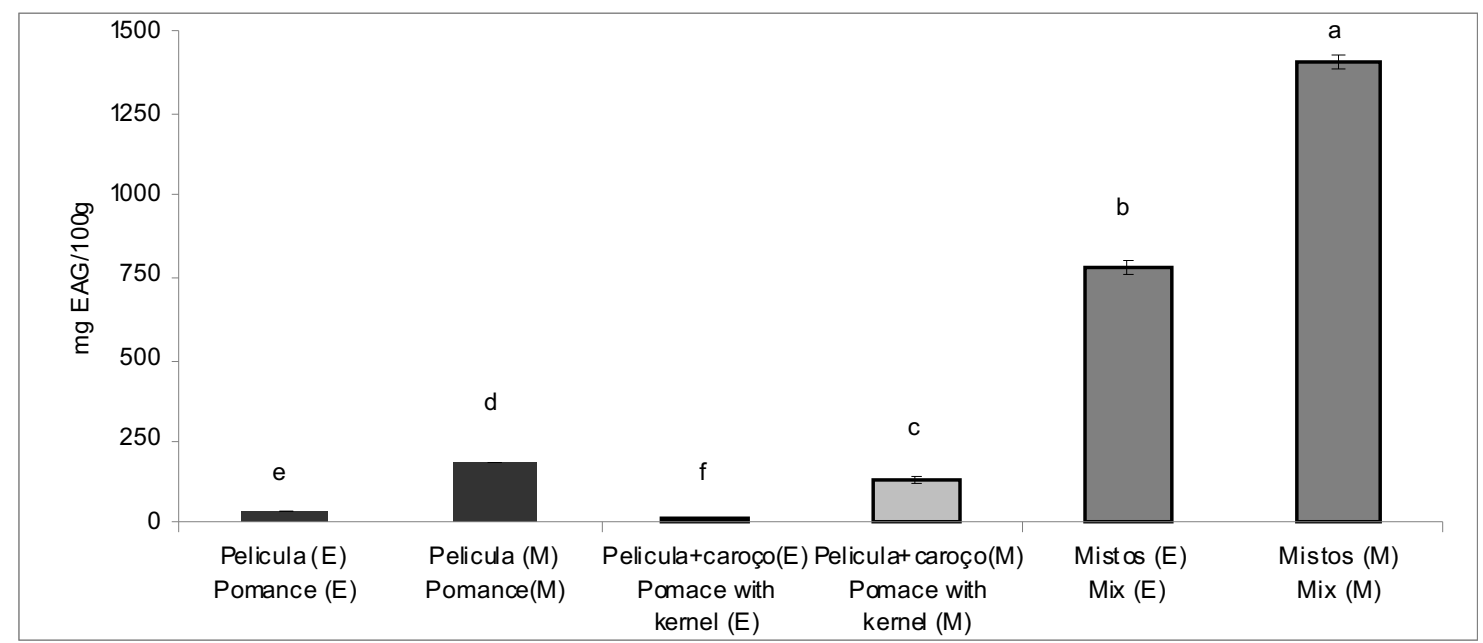

Figure 1 - Phenolic contents of ethanol (E) and methanol (M) extracts, prepared according to method $\mathrm{n}^{\circ} 1$. Values are presented as means \pm standard error. Bars with the same letter are not significantly $(p>0.05)$ different.

Figura 1 - Teor em fenóis totais das amostras extraídas com etanol (E) ou com metanol (M) de acordo com o método $n^{\circ} 1$. Os valores são apresentados como média \pm desvio padrão. Barras com letras diferentes não são significativamente diferentes, de acordo com o teste $t(p>0,05)$.

The comparison between the results obtained with methanol extracts prepared according to methods 1 and 2 showed no significant differences $(\mathrm{p}>0.05)$ for samples of pomace (skin and skin + kernel). However, there were significant differences $(p<0.05)$ in phenol contents of methanolic mix extract prepared according to method 1 or 2 , the values obtained with method $n^{\circ} 1$ being higher than those obtained with $\operatorname{method} \mathrm{n}^{\circ} 2$ (fig. 2 ). Thus, a shorter extraction time with more additions of fresh solvent does not seem to provide any advantage compared to a longer extraction procedure with less solvent renewal. On the contrary, extraction for less time with more additions of fresh solvent seems to contribute to a greater loss of the phenolic compounds present in leaves and stems.
A comparação dos resultados obtidos com os extractos metanólicos preparados de acordo com os métodos $n^{\circ} 1$ e 2 mostrou a inexistência de diferenças significativas $(\mathrm{p}>0,05)$ para as amostras de bagaço (película e película com caroço). Todavia, observaram-se diferenças significativas $(p<0,05)$ em relação às amostras mistas, tendo-se verificado valores de fenóis mais elevados para a extracção realizada de acordo com o método $\mathrm{n}^{\circ} 1$ (fig.2). Desta forma, extrair durante menos tempo com mais adição de solvente fresco não parece constituir uma mais valia em relação a um procedimento de extracção mais longo e com menos renovação de solvente, parecendo até contribuir para uma maior perda dos compostos fenólicos presentes nas folhas e pedúnculos. 


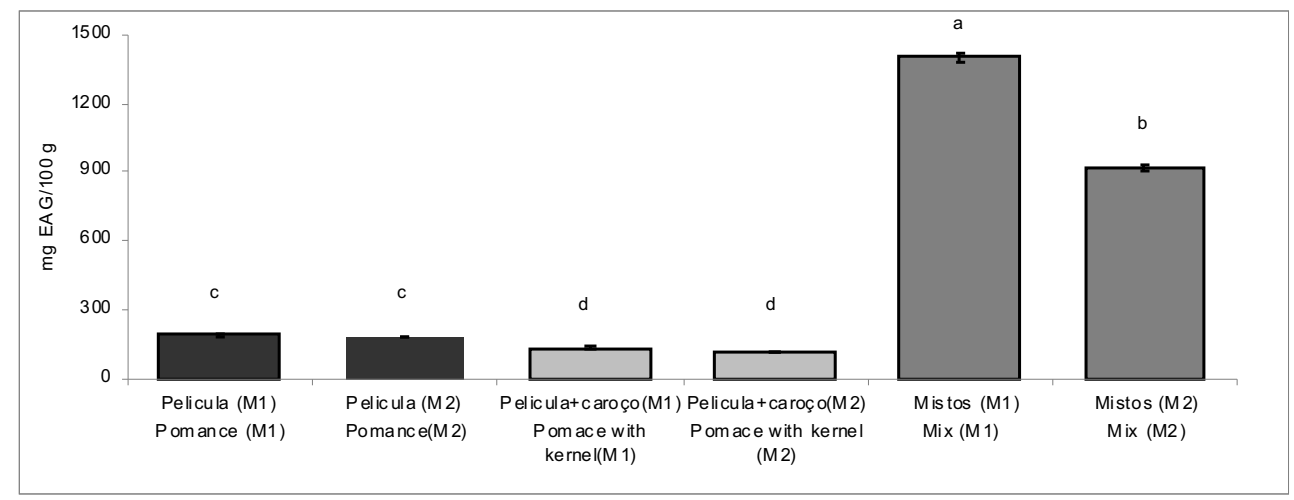

Figure 2 - Phenolic contents of methanol extracts prepared according to method $n^{\circ} 1(M 1)$ or method $n^{\circ} 2(M 2)$. Values are presented as means \pm standard error. Bars with the different letter are significantly different $(\mathrm{p}<0.05)$.

Figura 2 - Teor em fenóis totais das amostras extraídas com metanol de acordo com o método $\mathrm{n}^{\circ} 1$ (M1) ou com o método $\mathrm{n}^{\circ} 2$ (M2). Os valores são apresentados como média \pm desvio padrão. Barras com letras diferentes são significativamente diferentes, de acordo com o teste $\mathrm{t}(\mathrm{p}<0,05)$.

The determination of anthocyanin contents revealed the existence of this type of phenols in the skin samples (highest values) and skin with kernel samples, but not in mix extracts. Thus, it is possible to conclude that the anthocyanins are located preferentially in the skin of the fruits and not in the leaves or stems, as evidenced by the different colors presented by each of these plant fractions.

The anthocyanin contents were significantly higher ( $\mathrm{p}$ $<0.05$ ) in samples of skin than in samples of skin+kernel, being always significantly higher in extracts prepared with methanol than in extracts prepared with ethanol (fig. 3).
O doseamento de antocianinas revelou a existência deste tipo de fenóis nas amostras de película (valores mais elevados) e película com caroço, não tendo sido detectados nos extractos mistos. Desta forma, é possível concluir que as antocianinas se localizam preferencialmente na película dos frutos e não nas folhas ou nos pedúnculos facto evidenciado pelas diferentes cores apresentadas por cada uma destas partes da planta.

Os valores de antocianinas foram significativamente superiores $(\mathrm{p}<0,05)$ nas amostras de película do que nas amostras de película com caroço, tendo, igualmente, sido sempre significativamente superiores nos extractos preparados com metanol do que nos preparados com etanol (fig. 3).

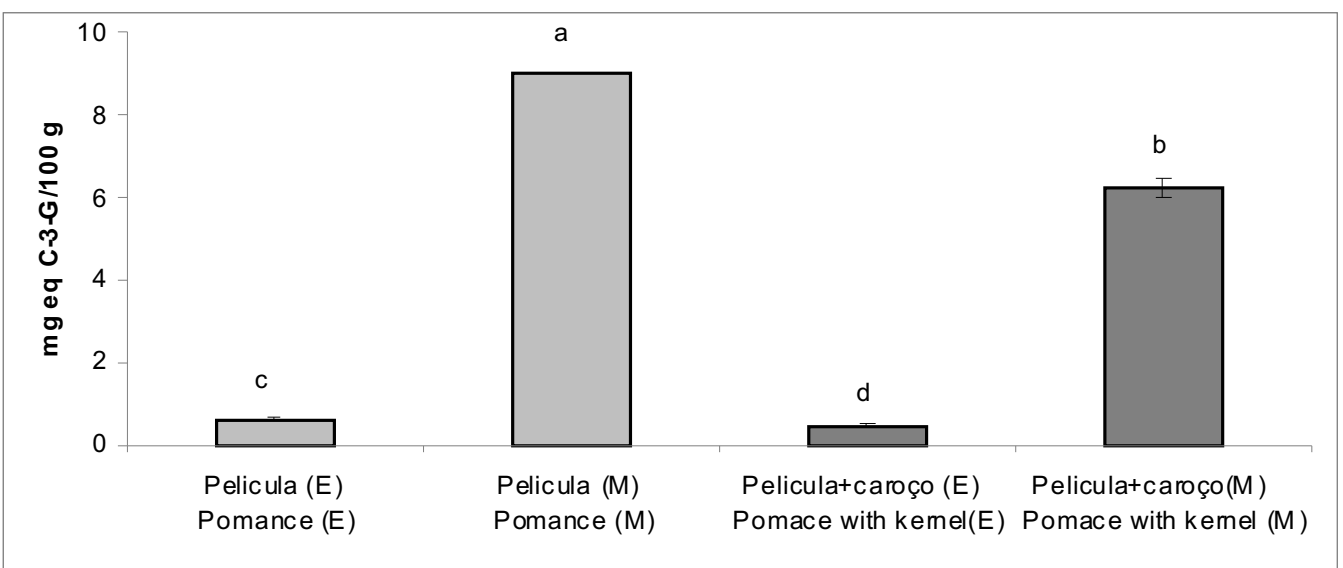

Figure 3 - Anthocyanin contents of ethanol (E) and methanol (M) extracts, prepared according to method $\mathrm{n}^{\circ} 1$. Values are presented as means \pm standard error. Bars with the different letter are significantly different $(\mathrm{p}<0.05)$.

Figura 3 - Conteúdo em antocianinas totais extraídas das amostras de bagaço de ginja com etanol (E) ou com metanol $(\mathrm{M})$ pelo método $\mathrm{n}^{\circ} 1$. Os valores são apresentados como média \pm desvio padrão. Barras com letras diferentes são significativamente diferentes, de acordo com o teste $\mathrm{t}(\mathrm{p}<0,05)$. 
Comparing the two extraction methods, no significant differences were observed concerning the anthocyanin contents in the complete samples (skin with kernel). However, significant differences $(p<0.05)$ were observed between the anthocyanin content of the skin without kernel samples, for the anthocyanin content of samples prepared according to method 1 were higher than those of samples prepared according to method 2 (fig. 4). The anthocyanin contents of complete samples were always lower than the anthocyanin contents of samples prepared only with skins (fig. 4). Thus, in relation to the anthocyanin contents, it can be concluded that methanol was the best solvent and that increasing the number of fresh solvent additions in the extraction procedure does not provide any advantage.

All the extracts showed a low anthocyanin content when compared with other results previously reported by other authors for fruit ${ }^{[17,18]}$, but they showed similar values when compared with other results previously reported by others authors for pomace by-products ${ }^{[19]}$.
Comparando os dois métodos de extracção foram observadas diferenças significativas $(p<0,05)$ entre o teor de antocianinas das amostras de película preparadas pelo método $\mathrm{n}^{\circ} 1$ e pelo método $\mathrm{n}^{\mathrm{o}} 2$, apresentando estas os valores mais elevados de antocianinas quando comparadas com as amostras de bagaço completo (película+caroço) (fig 4). Por outro lado, não foram observadas diferenças significativas $(\mathrm{p}>0,05)$ relativamente ao teor de antocianinas das amostras completas (película+caroço) preparadas quer pelo método 1 quer pelo método 2, que apresentaram os valores ligeiramente mais baixos (fig. 4). Desta forma, também em relação às antocianinas se pode concluir que o metanol é o solvente mais eficaz e que o aumento do número de extracções não representa uma mais valia.

Os extractos obtidos mostraram baixos conteúdos em antocianinas quando comparados com valores reportados por outros autores para o fruto ${ }^{[17,18]}$ mostrando valores similares aos encontrados por outros autores para os sub-produtos de bagaço ${ }^{[19]}$.

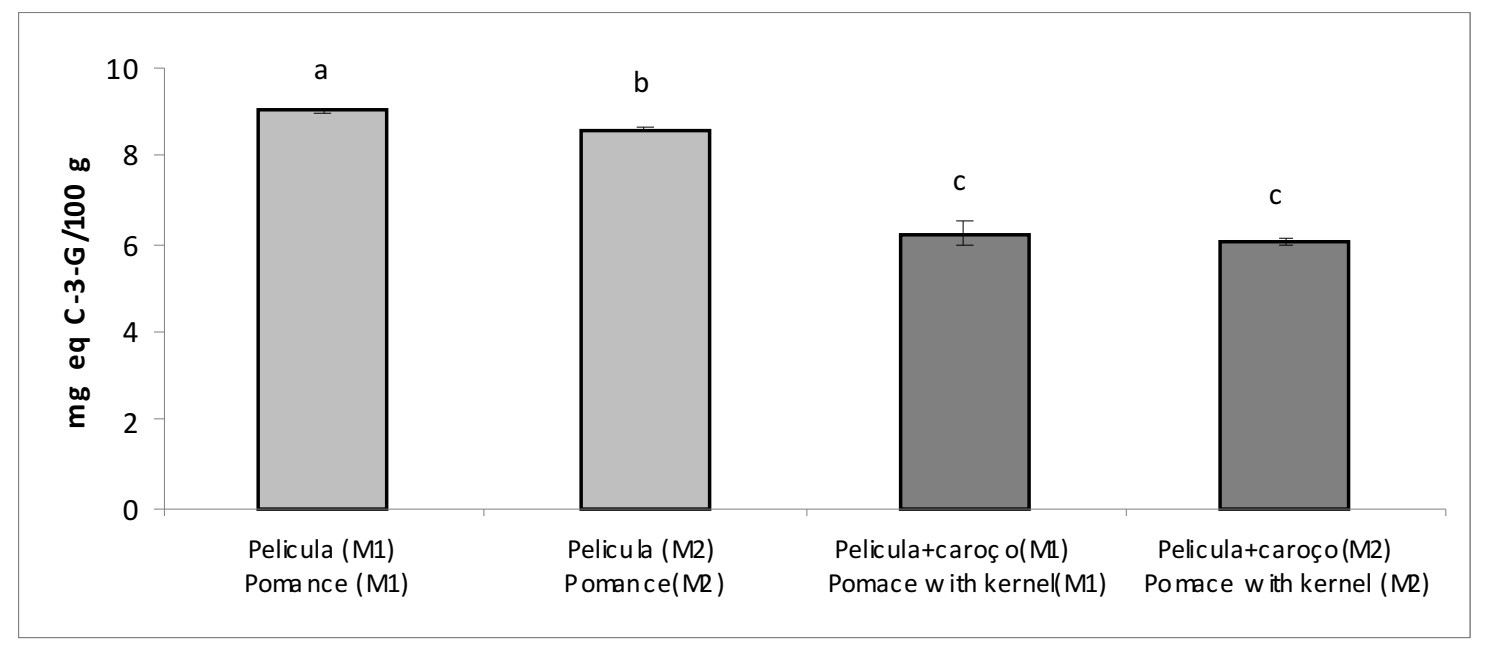

Figure 4 - Anthocyanin contents of methanol extracts prepared according to method $n^{\circ} 1$ (M1) or method $\mathrm{n}^{\circ} 2$ (M2). Values are presented as means \pm standard error. Bars with the different letter are significantly different $(\mathrm{p}<0.05)$.

Figura 4 - Teor em antocianinas totais das amostras extraídas com metanol de acordo com o método $\mathrm{n}^{\mathrm{o}} 1$ (M1) ou com o método $n^{\circ} 2$ (M2). Os valores são apresentados como média \pm desvio padrão. Barras com letras diferentes são significativamente diferentes, de acordo com o teste $t(p<0,05)$.

\section{Conclusions}

It was possible to extract phenolic compounds from all by-products of "Ginjinha" analyzed (leaves and stems, skin, and skin with kernel). The fraction composed by leaves and stems presented the highest total phenols content and the fraction composed by the skin presented

\section{Conclusões}

Foi possível extrair compostos fenólicos de todos os subprodutos da "Ginjinha" de Óbidos analisados (folhas e pedúnculos, película e película com caroço), tendo a fracção composta pelas folhas e pedúnculos sido aquela que apresentou teores mais elevados de fenóis totais e a 
the highest anthocyanin content.

The extraction of phenolic compounds was more efficient when the solvent used was methanol instead of ethanol, and when the extraction is carried out according to method 1, i.e. a longer extraction procedure and with less solvent renewals. Despite methanol having presented the best results, ethanol must continue to be studied for its safety and applicability in products for topical application and in food.

Thus, it is possible to conclude that the cherry skins pomaces, leaves and stems which were tested constitute an agro-industrial residue that can be seen as a promising low-cost source of phenolic compounds, with the potential to be incorporated into functional cosmetic formulations. The results obtained showed that there is a high potential for the valorization of these by-products, and additionally point out a way to reduce the environmental impact caused by their disposal.

Further studies will be conducted to address the antioxidant activity of "Ginjinha" by-products as well as its applicability as an ingredient in topical dermocosmetics. fracção composta pela película aquela que apresentou teores mais elevados de antocianinas.

A extracção destes compostos foi sempre mais eficiente quando o solvente utilizado foi o metanol e quando a extracção se efectuou de acordo com o método $n^{\circ} 1$, ou seja, a extracção mais lenta e com menor número de renovações do solvente pareceu ser a mais eficiente. Em relação à escolha do solvente, embora o metanol tenha sido o que apresentou os melhores resultados, o etanol terá de continuar a ser estudado pela sua segurança e aplicabilidade em produtos de aplicação tópica e na área alimentar.

Desta forma é possível concluir que os sub-produtos agro-industriais testados, películas com e sem caroço, folhas e pedúnculos de ginja são fontes promissoras de compostos fenólicos de baixo custo, com potencial para serem incorporados em formulações funcionais cosméticas. Os resultados obtidos permitem, assim, não só observar a existência de elevado potencial na valorização destes sub-produtos, como também, adicionalmente, observar uma forma de diminuir o impacto ambiental provocado pela sua eliminação.

Estudos futuros serão efectuados para avaliar a actividade antioxidante dos extractos destes subprodutos e a sua aplicabilidade como ingrediente tópico em dermocosmética.

\section{Conflito de Interesses}

Os autores declaram que não há relações pessoais e financeiros que poderiam ser vistas como apresentando

um potencial conflito de interesses.
The authors declare that there are no financial and personal relationships that could be viewed as presenting a potential conflict of interests.

\section{References / Referências}

[1]. Shukitt-Hale, B.; Lau, F.C.; Joseph, J.A. Berry Fruit Supplementation and the Aging Brain. J.Agric. Food. Chem. 2008, 56, 636-641.

[2].Eastwood, M.A. Interaction of Dietary Antioxidants in Vivo: How Fruit and Vege-tables Prevent Disease. Q. J. Med. 1999, 92, 527-530. [3]. Joseph, J.A.; Shukitt-Hale, B.; Casadesus, G. Reversing the Deleterious Effects of Aging on Neuronal Communication and Behavior: Beneficial Properties of Fruit Poly-phenolic Compounds. Am. J. Clin. Nutr. 2005, 81, 313S-316S.

[4]. Liu, Y.; Liu, X.; Zhong, F.; Tian, R.; Zhang, K.; Zhang, X.; Li, T. Comparative Study of Phenolic Compounds and Antioxidant Activity in Different Species of Cherries . J. of Food Science, 2011, 76, 4, C633-C638. [5]. Khoo, G.M.; Clausen, M.; Pedersen, B.; Erik, L. Bioactivity and total phenolic content of 34 sour cherry cultivars. J. Food Compos.Anal. 2011, 24(6), 772-776. [6]. Youdim, K.A.; Spencer, J.P.; Schroeter, H.; Rice-Evans, C. Dietary Flavonoids as Potential Neuroprotectants. Biol. Chem. 2002, 383, 503-519. [7]. Plattila, P.; Hellstrom, J.; Törrönen, R. Phenolic Acids in Berries, Fruits, and Bever-ages. J. Agric. Food. Chem. 2006, 54, 7193-7199.

[8]. Dani, C.; Oliboni, L.S.; Vanderlinde, R.; Bonatto, D.; Salvador, M.; Henriques, J.A.P.
Phenolic Content and Antioxidant Activities of White and Purple Juices Manufactured with Organically or Conventially Produced Grapes. Food and Chem. Toxicol. 2007, 45, 2574-2580.

[9]. Moure, A.; Cruz, J.M.; Franco, D.; Dominguez, J.M.; Siherio, J.; Dominguez, H. Natural Antioxidants from Residual Sources. Food Chem. 2001, 72, 145-171.

[10]. Hernanz, D.; Recamales, F.A.; Gonzalez-Miret, M.L.; Gomez-Miguez, M.J.; Vi-cario, I.M.; Heredia, F.J. Phenolic Composition of White Wines with a Prefermentative Maceration at Experimental and Industrial Scale. J. of Food Eng. 2007, 80, 327-335.

[11]. Boyer, J.; Liu, R.H. Apple phytochemicals and their health benefits. Nutr J. 2004, 12;3:5.

[12]. Blando, F.; Gerardi, C.; Nicoletti, I. Sour Cherry (Prunus cerasus L) Anthocyanins as Ingredients for Functional Foods. J. Biomed. Biotechnol. 2004, 5, 253-258.

[13]. Connor, A.; Luby, J.; Tong, C. Genotypic and environmental variation in antioxidant Activity, Total phenolic Content, and Anthocyanin Content among blueberry cultivars.J. Ame.Soc.Hort.Sci. 2002 ;127(1): 89-97. [14]. Prior, R.L.; Wu, X.; Schaich, K. Standardized methods for the determination of antioxidant capacity and phenolics in foods and dietary supplements. J. Agric. Food. Chem. 2005, 53, 4290-4302.

[15]. Kosar, M.; Fatih, G.; Baser, K.H.C. In vitro antioxidant properties and phenolic composition of Salvia virgata Jacq. from Turkey. J. Agric. Food. Chem. 2008, 56, 2369-2374.

[16].Lee, J.; Durst, R.W.; Wrolstad, R.E. Determination of total monomeric anthocyanin pigment content of fruit juices, beverages, natural colorants, and wines by the $\mathrm{pH}$ Differential Method: Collaborative Study. The Journal of AOAC International. 2005, 88, 269-278.

[17]. Piccolella, S.; Fiorentino, A.; Pacifico, S.; D'Abrosca, B.; Uzzo, P.; Monaco, P. Antioxidant properties of sour cherries (Prunus cerasus L.): role of colorless phytochemicals from the methanolic extract of ripe fruits. J Agric Food Chem. 2008, 56(6),1928-1935.

[18]. Pantelidis, G.; Vasilakakis, G.; Diamantidis, G. Antioxidant capacity, phenol, anthocyanin and ascorbic acid contents in raspberries, blackberries, red currants, gooseberries and Cornelian cherries. Food Chem. 2007, 102,777-783.

[19]. Serra, A.; Duarte, R.; Bronze, M.; Duarte, C. Identification of bioactive response in traditional cherries from Portugal. Food Chem. 2011,125, 318-325. 